\title{
Effect of substratum drying on the survival and migrations of a freshwater pulmonate snail Planorbarius corneus (Linnaeus, 1758)
}

\author{
Małgorzata Poznańska • Dorota Goleniewska • \\ Tomasz Gulanicz • Tomasz Kakareko • \\ Lukasz Jermacz $\cdot$ Jarosław Kobak
}

Received: 13 March 2014/Revised: 22 November 2014/ Accepted: 25 November 2014/Published online: 9 December 2014

(C) The Author(s) 2014. This article is published with open access at Springerlink.com

\begin{abstract}
Pulmonate snails inhabiting the near-shore zone of water bodies experience air exposure during water level fluctuations and some of them are known to survive long time in temporary basins. In laboratory, we investigated survival and behavioural defences (horizontal migrations and burrowing in substratum) of adult pulmonate snails Planorbarius corneus during substratum (sand and organic-rich) drying. We examined horizontal migrations at shorter and longer distances (24 and $48 \mathrm{~cm}$ ), during gradual (8 days) or sudden water level drop rates. $P$. corneus was remarkably resistant to substratum drying, surviving 50 days on sand and more than 53 days on organic-rich bottom. The snails followed the retreating water level and grouped in the submerged parts of experimental tanks. This response was reduced on organic-rich bottom at a longer distance and with water level decreasing suddenly. Moreover, snails exposed to drying buried shallowly in both bottom
\end{abstract}

Handling editor: Sonja Stendera

M. Poznańska ( $\square) \cdot$ D. Goleniewska ·

T. Gulanicz · Ł. Jermacz · J. Kobak

Department of Invertebrate Zoology, Faculty of Biology

and Environmental Protection, Nicolaus Copernicus

University, Lwowska 1, 87-100 Toruń, Poland

e-mail: mpoznan@umk.pl

T. Kakareko

Department of Hydrobiology, Faculty of Biology and

Environmental Protection, Nicolaus Copernicus

University, Lwowska 1, 87-100 Torun, Poland types. Thus, $P$. corneus exhibited variable and efficient strategies enabling its survival during water level fluctuations, including active migrations following the retreating water level and burying in sediments.

Keywords Desiccation - Drought tolerance - Water level fluctuations - Sand · Organic-rich sediments . Gastropods

\section{Introduction}

Snails, especially pulmonates, inhabit the near-shore zone of water bodies (e.g. Lodge, 1985; Underwood et al., 1992; Costil \& Clement, 1996), which is strongly affected by water level fluctuations (e.g. Coops et al., 2003; Furey et al., 2004; Poznańska et al., 2009). The effect of water level changes on fauna and flora depends on their range, duration, regularity and frequency, as well as on season, basin morphometry, bottom type and climate (e.g. Richardson et al., 2002; Brauns et al., 2008; Poznańska et al., 2010). In the future, climate change is likely to increase the frequency and intensity of droughts in many river basins (e.g. van Vliet \& Zwolsman, 2008) and to decrease the water level of lakes (Overpeck \& Udall, 2010; Abbaspour et al., 2012). Water level fluctuations and temporary air exposures belong to the most important factors affecting invertebrate communities in the near-shore zone (Costil et al., 2001). When the water level drops in summer, bottom dwellers such as freshwater snails are in danger of desiccation, anoxia 
and starvation, associated with air exposure (Ferreira et al., 2003; White et al., 2006; Akande et al., 2010).

Freshwater gastropods include gill-breathing prosobranchs and air-breathing pulmonates that differ from each other in the degree of adaptation to aquatic life (Aldridge, 1983; McMahon, 1983). According to Machin (1975) and McMahon (1983), due to their terrestrial origin, most freshwater pulmonates are highly tolerant to prolonged aerial exposure. Their aerial mode of respiration is efficient in shallow, eutrophic environments, where exposure to air, desiccation and hypoxia can be frequent. Nevertheless, they may be limited by the amount of dissolved oxygen as they do not occur in waters with oxygen saturation below $1.3 \%$ (Tanveer \& Kahn, 1989). According to Ghiretti \& Ghiretti-Magaldi (1975) and McMahon (1983), freshwater pulmonates show various degrees of readaptation to aquatic life, increasing from Lymnaeidae (with a typical lung), through Physidae, to the best adapted Planorbidae and Acroloxidae. They can use dissolved oxygen through cutaneous respiration, and the two latter families have developed an accessory, neomorphic gill. Other adaptations of Planorbidae include haemoglobin as an oxygen transporter (more efficient than haemocyanin found in other pulmonates), ureotelism (allowing for retention of nitrogenous wastes in haemolymph) and efficient facultative anaerobic metabolism. This allows them to survive in hypoxic conditions, for instance when they bury in sediments, Planorbidae can resist totally anoxic conditions for up to $64 \mathrm{~h}$ (von Brand et al., 1950).

A special physiological adaptation of some freshwater gastropods to prolonged air exposure is aestivation (Machin, 1975; Livingstone \& de Zwaan, 1983). This is an aerobic dormancy exhibited in arid conditions including the lack of water and food as well as high temperatures (Nowakowska, 2011). Pulmonate snails endure such conditions by retracting into their shells, secreting a thick mucous membrane or epiphragm, depressing their metabolic rate and aestivating for months or even years until re-appearance of favourable environmental conditions (Parashar \& Rao, 1998; Nowakowska, 2011). Aestivating freshwater pulmonates rely on anaerobic breathing, as their pneumostome is closed (Alâkrinskaâ, 1971). Metabolic depression extends the period of survival without oxygen (Ferreira et al., 2003). As snails starve during aestivation, they use their depot resources for energy (e.g. Goddard \& Martin, 1966; Livingstone \& de Zwaan, 1983; White et al.,
2006). There are many examples of planorbids from temporary basins aestivating without water for 1-2 years (e.g. Klekowski, 1959 after Precht, 1939; Richards, 1967; Ferreira et al., 2003).

The second strategy to avoid desiccation is active migration of mobile organisms to more favourable areas (McMahon, 1983; Poznańska et al., 2013). Snails following the retreating water level move to small pools created in depressions (Extence, 1981), or to moist debris and macrophytes remaining on the exposed shore (Piechocki, 1979).

Yet another strategy is burying into deeper, more humid and cooler sediment layers (e.g. Gough et al., 2012; Kapps \& Haase, 2012). In some cases burying behaviour precedes aestivation (Machin, 1975).

We chose Planorbarius corneus Linnaeus, 1758 (Planorbidae) as a pulmonate snail model species, as it typically inhabits near-shore zones of water bodies subjected to temporary air exposures. $P$. corneus lives in ponds, lakes and slowly flowing waters with rich macrophyte cover (Piechocki, 1979). It is a common inhabitant of central European wetlands (Jopp, 2006) and temporary basins (Klekowski, 1959; Piechocki, 1979; Jurkiewicz-Karnkowska, 2008). Therefore, we hypothesised that this snail would exhibit some behavioural adaptations to air exposure, such as burying into substratum and horizontal migration, which have not been investigated yet.

We examined experimentally the survival and behavioural responses of $P$. corneus during substratum drying. We wanted to determine the depth of burrowing by this snail as well as the distance at which it can move following the decreasing water level. Additionally, we investigated if its horizontal migrations were affected by the rapidity of the change in water conditions (gradual vs. sudden water level drop). We tested two types of substrata affecting the survival and migrations of tested snails: sandy bottom, typical for littoral zones and organic-rich sediments. We assumed that survival and burying behaviour would be better in organic-rich substratum, providing better protection against desiccation.

\section{Materials and methods}

Sampling and experimental conditions

We collected the individuals of $P$. corneus from a reed bed in the Gopło Lake (north-central Poland, 
Table 1 Physical and chemical properties of water during the experiments on two types of substrata and in the stock tanks

\begin{tabular}{|c|c|c|c|c|c|}
\hline & $\begin{array}{l}\text { Oxygen } \\
\text { concentration } \\
(\mathrm{mg} / \mathrm{l})\end{array}$ & $\begin{array}{l}\text { Oxygen } \\
\text { saturation } \\
(\%)\end{array}$ & $\begin{array}{l}\text { Temperature } \\
\left({ }^{\circ} \mathrm{C}\right)\end{array}$ & $\mathrm{pH}$ & $\begin{array}{l}\text { Conductivity } \\
(\mu \mathrm{S} / \mathrm{cm})\end{array}$ \\
\hline \multicolumn{6}{|c|}{ Sandy substratum } \\
\hline Mean & 7.5 & 82.0 & 19.9 & 8.4 & 590 \\
\hline Minimum & 4.8 & 56.2 & 16.7 & 8.1 & 466 \\
\hline Maximum & 9.1 & 94.4 & 22.2 & 8.5 & 921 \\
\hline SD & 1.06 & 9.78 & 1.50 & 0.13 & 111.96 \\
\hline \multicolumn{6}{|c|}{ Organic-rich sediments } \\
\hline Mean & 5.0 & 53.4 & 19.6 & 8.1 & 708 \\
\hline Minimum & 2.5 & 28.3 & 16.9 & 7.6 & 560 \\
\hline Maximum & 7.0 & 73.2 & 22.5 & 8.3 & 875 \\
\hline SD & 0.86 & 8.37 & 1.74 & 0.17 & 103.34 \\
\hline \multicolumn{6}{|l|}{ Stock tanks } \\
\hline Mean & 7.1 & 81.4 & 22.4 & 8.3 & 665 \\
\hline Minimum & 6.3 & 74.4 & 20.3 & 7.82 & 550 \\
\hline Maximum & 9.0 & 100.3 & 23.8 & 8.64 & 755 \\
\hline SD & 1.14 & 10.85 & 1.41 & 0.32 & 85.72 \\
\hline
\end{tabular}

daily with a thermo-hygrometer (EMR812HGN, Oregon Scientific, UK), were in average $21.5^{\circ} \mathrm{C}$ (range $19.1-23.6^{\circ} \mathrm{C}$, SD 1.14 ) and $44.3 \%$ (32-64\%, SD 8.08), respectively. We monitored water quality (oxygen concentration, temperature, $\mathrm{pH}$, conductivity) at the beginning and at the end of the tests using a multimeter Multi340i (WTW GmbH, Weilheim, Germany), except when water level was too low to submerge the probes of the measuring device. Water quality during our experiments was good and suitable for survival of aquatic organisms (Table 1). We also determined the substratum water content at the end of each test, calculating it from the difference in the weight of a sediment sample (ca $8 \mathrm{~g}$ of sand and ca $5.6 \mathrm{~g}$ of organic-rich material) before and after drying it for $24 \mathrm{~h}$ at $100^{\circ} \mathrm{C}$.

We conducted the experiments in water aerated for $24 \mathrm{~h}$ before use. We carried out 5 replicates for each substratum type, with water level dropping down and exposing the substratum. To fasten this process, we removed a small amount of water (ca $100 \mathrm{ml}$ ) daily from the experimental vessels with a syringe. Hereafter, this treatment will be referred to in the text as "drying". Each experiment also included 5 control replicates run under the same conditions but with a constant water level. Hereafter, this treatment will be referred to in the text as "control". We checked snail behaviour and survival in the control trials at the same times as in the drying treatments. As the individuals in 
the drying treatments could not feed without water, we did not feed the control snails as well.

\section{Experiment 1: survival}

We used glass trays to which, after $24 \mathrm{~h}$ of substratum conditioning, we introduced 7 snails (Fig. 1A). Based on our preliminary observations, at the beginning of the exposure, we determined the mortality of snails in 6-day intervals and, after the 18th day in 3-day intervals, counting from the day on which the substratum was exposed to air. All snails after the test were put into a tank with water, to determine their survival. After $24 \mathrm{~h}$, living individuals moved in the tank and dead individuals gave off a smell of decomposing tissue. We conducted the experiment until the 53rd day, although the intention was to run the experiment until death of all gastropods. However, many of them were still alive after almost 2 months in a completely dry substratum. Unfortunately, we had to stop our experiment at this point, as the snails in the control trays started to die off similarly to those from the drying trays. Thus, some other factors, independent of air exposure, must have affected their survival after this period, which made further tests on the effect of drying on snail survival impossible.

\section{Experiment 2: horizontal migrations}

We conducted this experiment in inclined glass tanks (Fig. 1B) in three variants: (1) short tanks $(24 \mathrm{~cm})$ with a gradual water level drop lasting for 8 days, (2) long tanks $(48 \mathrm{~cm})$ with a gradual water level drop (8 days), (3) long tanks with a sudden water level drop. We assumed that snails could respond to the water level drop by moving down the inclined surface to follow the retreating water line, or by staying in the exposed area. We tested the effect of the distance from a submerged zone (the first two variants) and a rapidity of the water drop (the third variant) on snail
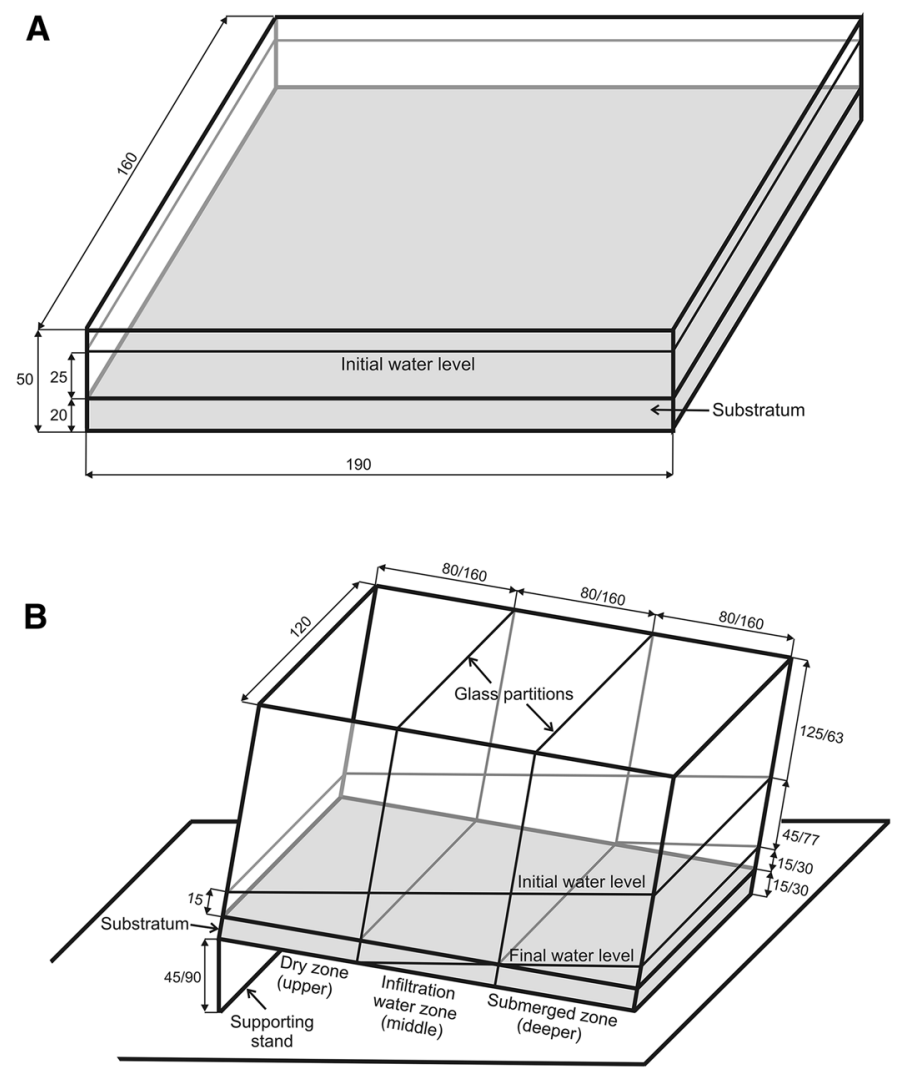

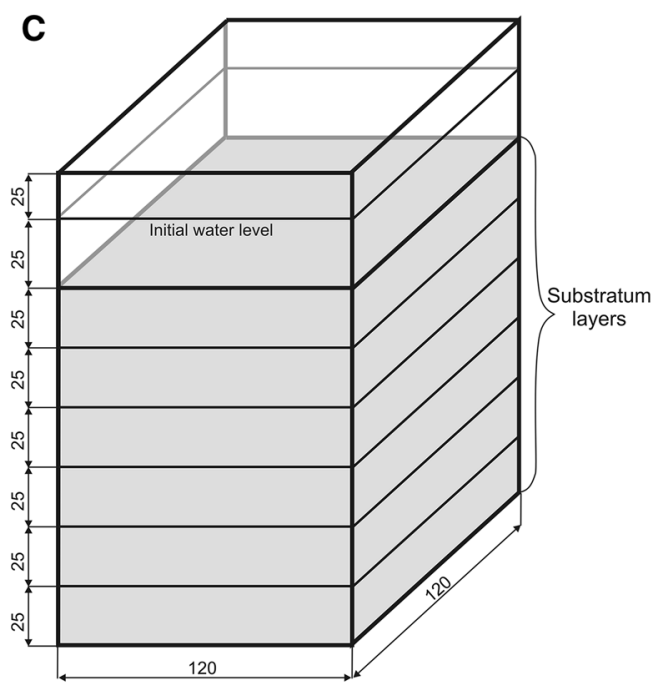

Fig. 1 Experimental vessels used in A Experiment 1, B Experiment 2 (double dimensions refer to short and long tanks, respectively), and $\mathbf{C}$ Experiment 3. The dimensions are given in $\mathrm{mm}$ 
migrations. After $24 \mathrm{~h}$ of conditioning of submerged substratum, we divided the tank into three equal zones with glass barriers and added 5 snails to one of the side zones of the tank. After the next $24 \mathrm{~h}$, we raised the shorter wall of the tank, adjacent to the snail introduction zone so that it was elevated 4.5 or $9 \mathrm{~cm}$ (in short and long tanks, respectively, to keep the constant inclination angle of $10.8^{\circ}$ ) above the table surface. This imitated the shore inclination (Fig. 1B). Then, we removed the barriers and let the animals disperse. In the control tanks, the water level was kept at a constant level of $1.5 \mathrm{~cm}$ in the shallowest place. In the gradually drying tanks (variants \#1 and 2), we finished the experiment, when the water dropped to the final level indicated in Fig. 1B. In the variant with a sudden water level drop (variant \#3), we removed all the water above the final level shown in Fig. 1B immediately after raising the tanks and continued the exposure for the next $24 \mathrm{~h}$. According to our preliminary trials, the distribution of snails did not change after further extension of exposure time. At the end of the trial, the substratum consisted of three equal zones (Fig. 1B), starting from the raised side of the tank: (1) dry zone: air-exposed bottom with humid substratum, (2) infiltration water zone: air-exposed bottom with infiltration water below the substratum surface and (3) submerged zone. At this moment, we determined the number of snails and their mortality in each zone. The mortality was checked according to the method used for Experiment 1 (see above).

\section{Experiment 3: vertical migrations}

We used glass tanks filled with a thick layer of substratum (Fig. 1C). After $24 \mathrm{~h}$ of conditioning of submerged substratum, we introduced 5 snails to each tank. One day after the substratum in the drying tanks became exposed to air, we determined the number of snails in six $2.5-\mathrm{cm}$ vertical substratum layers. The experiment lasted for 6-8 days.

\section{Statistical analysis}

The high survival and desiccation-independent mortality of snails in Experiment 1 made it impossible to calculate formally LT50 and LT90 values in Experiment 1. In the results, we refer the survival of snails to the time they spent on the air-exposed substratum.
We used one-sample $t$ tests to check snail selectivity for particular tank zones in Experiment 2. We compared the mean percentage of animals found in a given tank zone with a theoretical value of $33.3 \%$, assuming their random distribution among the zones.

Moreover, we run a series of ANOVAs on logtransformed percentages of individuals found in a given tank zone to check for the effects of various factors on snail behaviour. We applied 3-way ANOVAs to the data from gradually drying variants, with treatment (drying or control), substratum type and tank length as factors. We also run a 2-way ANOVA on the data from long drying tanks, to test the effects of substratum type and water drop rate. We ran a separate analysis for each of the three zones in the tanks. Furthermore, we compared the water content levels between the zones in each variant using oneway within-subject ANOVAs.

As in Experiment 3 snails did not migrate deeply into the substratum, burying only just below the surface, we simply analysed the log-transformed percentages of all buried animals using a two-way ANOVA with substratum type and treatment as factors.

\section{Results}

Experiment 1: survival

On the first day without water on the surface, the substratum contained $13 \%$ (sand) or $64 \%$ (organicrich sediments) of water. On the 6th day of drying, the water content decreased to $0.1 \%$ in the sandy substratum and to $54 \%$ in organic-rich bottom. In the control trays, average water content was 20 and $71 \%$ in sandy and organic-rich sediments, respectively.

Our experiments lasted for 50 and 53 days for sandy and organic-rich bottom, respectively. We observed high fluctuations of survival in the drying trays (Fig. 2A, B). A serious drop in survival (down to $14 \%$ ) was observed on the 51st day of drying on sand (Fig. 2A) and on the 39th day on organic-rich sediments (Fig. 2B). In the control trays, survival abruptly decreased on the 39th day to 57 and $71 \%$ on sandy and organic-rich bottom, respectively, and remained on these levels almost till the end of the experiment. At the end of the experiment, all snails exposed to desiccation on the sandy bottom died, 

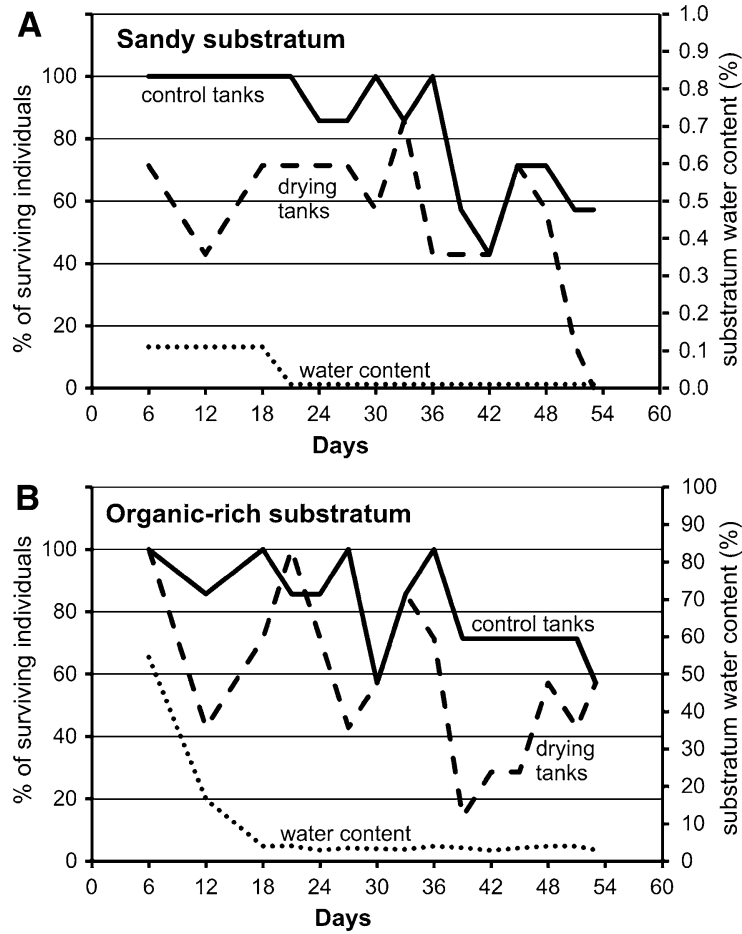

Fig. 2 Survival (\%) of control (solid lines) and air-exposed (dashed lines) snails on $\mathbf{A}$ sandy and $\mathbf{B}$ organic-rich bottom as well as the water content (\%) (dotted lines) in sediments (Experiment 1)

whereas more than $50 \%$ of individuals kept on the drying organic-rich substratum were still alive (Fig. 2). Unfortunately, the control individuals started to die out after a longer exposure (Fig. 2B) irrespective of drying, which made us end the experiment before reaching $100 \%$ mortality.

\section{Experiment 2: horizontal migrations}

The substratum water content in the drying organicrich bottom ( $66 \%$ on average, all zones and treatments pooled) was higher than in sand (20\%). In the drying tanks, water content differed significantly among the zones (Table 2). In the control tanks, we observed no significant differences between the zones, except the short tanks with organic-rich bottom.

Snails in the drying tanks followed the decreasing water level (Fig. 3), resulting in lower numbers found in the dry zone (ANOVA, Drying variant effect: $\left.F_{1,33}=4.2, P=0.048\right)$ and greater numbers found in the submerged zone $\left(F_{1,33}=9.1, P=0.005\right)$ than in the control tanks (Table 3A). Their behaviour also depended on distance (Tank length effect: $F_{1}, \quad 33=4.4, P=0.044$, Table 3A), with more intense movement to the submerged zone observed in the short tanks, as well as on substratum type (Substratum effect: $F_{1}, \quad 33=7.5, \quad P=0.010$, Table $3 \mathrm{~A}$ ), with greater translocations occurring on sand (Fig. 3).

In the gradually drying short tanks, 76 and $72 \%$ of individuals followed the decreasing water level to the submerged zone on sandy and organic-rich bottom, respectively (Fig. 3A, C). The dry zone was only occupied by 16 and $8 \%$ of the tested snails, respectively. In the short control tanks, the percentages of snails varied between 16 and $40 \%$ in the upper zone and $44-56 \%$ in the deeper zone, with no significant departures from the random distribution (Fig. 3).

In the longer tanks the distribution on sandy bottom was similar to that in the short tanks, with $68 \%$ of individuals moving towards the submerged zone (Fig. 3B). However, on organic-rich bottom, the distribution in the drying tanks did not depart from the random distribution, with 27 and $43 \%$ of snails occupying the dry and submerged zones, respectively (Fig. 3D). In the control tanks with organic-rich bottom, $50 \%$ of snails, significantly more than predicted by the random distribution, grouped in the upper zone.

After a sudden water level drop migrations towards the submerged zone were less pronounced than those observed during gradual drying (ANOVA, Drying time effect: $F_{1}, 1_{16}=14.1, \quad P=0.002$ and $F_{1,16}=12.4, P=0.003$ for the upper and low zone, respectively, Table 3B). In these conditions, 44 and $83 \%$ snails stayed in the dry zone on sandy and organic-rich bottom, respectively (Fig. 3B, D). Nevertheless, some snails, particularly on sand, did migrate to the interstitial (24\%) and submerged zone (32\%). On the detritus-rich bottom, only $17 \%$ of individuals translocated to the submerged zone of the suddenly drying tanks.

\section{Experiment 3: vertical migrations}

The substratum water content in the surface zone, where snails occurred, was $10.4 \pm 1.3 \mathrm{SE} \%$ on sandy bottom and $78.6 \pm 2.4 \mathrm{SE} \%$ on organic-rich bottom.

The tested snails buried themselves just below the substratum surface (40 and 52\% in the organic-rich 
Table 2 Substratum water content $(\%)($ mean $\pm \mathrm{SE})$ in Experiment 2 (horizontal migrations)

Zones labelled with the same superscript letter did not differ significantly from one another in ANOVA

\begin{tabular}{|c|c|c|c|c|c|c|c|c|}
\hline \multirow[t]{2}{*}{ Tank } & \multirow[t]{2}{*}{ Substratum } & \multirow[t]{2}{*}{ Treatment } & \multicolumn{3}{|l|}{ Zones } & \multicolumn{3}{|c|}{ ANOVA } \\
\hline & & & $\begin{array}{l}\text { Dry/ } \\
\text { upper }\end{array}$ & $\begin{array}{l}\text { Infiltration/ } \\
\text { middle }\end{array}$ & $\begin{array}{l}\text { Submerged/ } \\
\text { deeper }\end{array}$ & df & $F$ & $P$ \\
\hline Short & Sand & Drying & $18 \pm 0.2^{\mathrm{a}}$ & $19 \pm 0.1^{\mathrm{b}}$ & $20 \pm 0.2^{\mathrm{c}}$ & 2 & 26.90 & $<0.001$ \\
\hline Long & Sand & Drying & $18 \pm 0.2^{\mathrm{a}}$ & $19 \pm 0.1^{\mathrm{b}}$ & $21 \pm 0.3^{\mathrm{c}}$ & 2 & 130.65 & $<0.001$ \\
\hline Short & Sand & Control & $20 \pm 0.3^{\mathrm{d}}$ & & $21 \pm 0.6^{\mathrm{d}}$ & 1 & 0.97 & 0.380 \\
\hline Long & Sand & Control & $20 \pm 0.7^{\mathrm{d}}$ & & $20 \pm 0.8^{\mathrm{d}}$ & 1 & 0.03 & 0.863 \\
\hline Short & Organic-rich & Drying & $79 \pm 5.7^{\mathrm{a}}$ & $76 \pm 2.8^{\mathrm{b}}$ & $48 \pm 4.5^{\mathrm{c}}$ & 2 & 10.42 & 0.006 \\
\hline Long & Organic-rich & Drying & $63 \pm 1.1^{\mathrm{a}}$ & $65 \pm 0.8^{b}$ & $69 \pm 1.1^{\mathrm{c}}$ & 2 & 14.02 & 0.002 \\
\hline Short & Organic-rich & Control & $70 \pm 1.9^{\mathrm{a}}$ & & $54 \pm 2.5^{\mathrm{b}}$ & 1 & 32.12 & 0.005 \\
\hline Long & Organic-rich & Control & $69 \pm 0.8^{\mathrm{d}}$ & & $70 \pm 0.9^{\mathrm{d}}$ & 1 & 4.49 & 0.102 \\
\hline
\end{tabular}
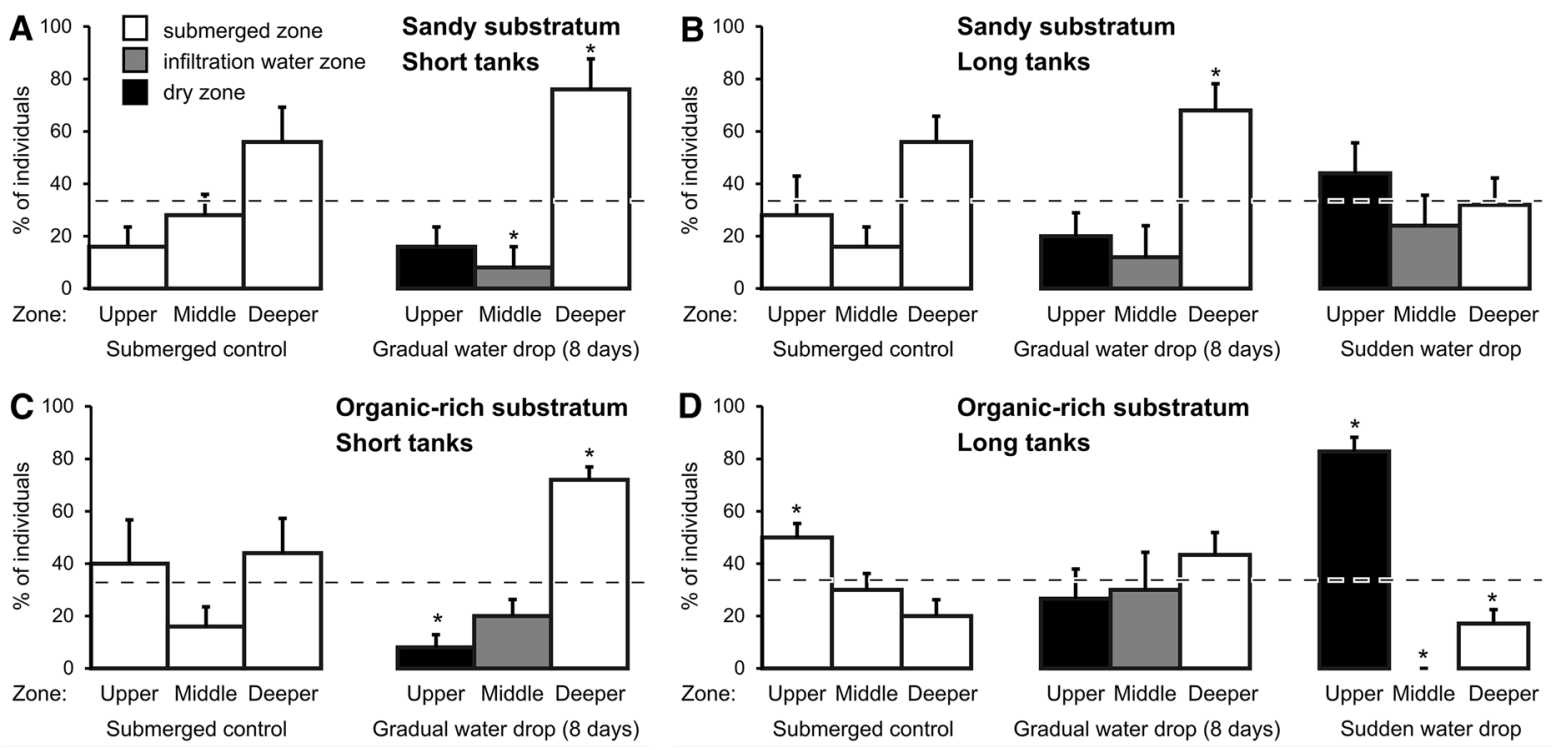

Fig. 3 Horizontal migrations of snails following the decreasing water level on A, B sandy and $\mathbf{C}, \mathbf{D}$ organic-rich substratum in A, C short and B, D long tanks (Experiment 2). White, grey, and black bars stand for the percentages of snails occupying submerged, infiltration water and dry zones, respectively. The

error bars show standard errors of means (SE). The asterisks indicate significant departures of snail percentages in a particular tank zones from a theoretical value of $33.3 \%$ (dashed line), indicating a random distribution (one-sample $t$ test)

and sandy substratum, respectively) (Fig. 4), never migrating deeply into the sediments. This was only observed in the drying tanks, resulting in a significant Drying variant effect in ANOVA $\left(F_{1,16}=23.1\right.$, $P<0.001$, Table 3C), whereas in the control tanks all snails remained on the substratum surface.

\section{Discussion}

We studied the behaviour and survival strategies of the freshwater pulmonate snail Planorbarius corneus exposed to air through water level fluctuations, commonly occurring in shallow freshwater habitats 
Table 3 Statistical analysis of snail movement in Experiment 2 and 3

\begin{tabular}{cccccc}
\hline Effect & $\mathrm{df}_{\text {effect }}, \mathrm{df}_{\text {error }}$ & $\mathrm{MS}_{\text {effect }}, \mathrm{MS}_{\text {error }}$ & $F$ & $P$ \\
\hline
\end{tabular}

A. Horizontal movement: gradual water drop, drying versus control tanks

Shallow zone

\begin{tabular}{|c|c|c|c|c|}
\hline Substratum (S) & 1,33 & $0.07,0.03$ & 2.13 & 0.154 \\
\hline Tank length (L) & 1,33 & $0.08,0.03$ & 2.50 & 0.123 \\
\hline Drying variant (D) & 1,33 & $0.14,0.03$ & 4.22 & $0.048 *$ \\
\hline $\mathrm{S} \times \mathrm{L}$ & 1,33 & $0.01,0.03$ & 0.35 & 0.558 \\
\hline $\mathrm{S} \times \mathrm{D}$ & 1,33 & $0.08,0.03$ & 2.59 & 0.117 \\
\hline $\mathrm{L} \times \mathrm{D}$ & 1,33 & $0.00,0.03$ & 0.00 & 0.997 \\
\hline $\mathrm{S} \times \mathrm{L} \times \mathrm{D}$ & 1,33 & $0.01,0.03$ & 0.20 & 0.657 \\
\hline \multicolumn{5}{|l|}{ Middle zone } \\
\hline Substratum (S) & 1,33 & $0.05,0.03$ & 1.88 & 0.179 \\
\hline Tank length (L) & 1,33 & $0.01,0.03$ & 0.30 & 0.587 \\
\hline Drying variant (D) & 1,33 & $0.03,0.03$ & 0.98 & 0.330 \\
\hline $\mathrm{S} \times \mathrm{L}$ & 1,33 & $0.04,0.03$ & 1.59 & 0.216 \\
\hline $\mathrm{S} \times \mathrm{D}$ & 1,33 & $0.04,0.03$ & 1.39 & 0.247 \\
\hline $\mathrm{L} \times \mathrm{D}$ & 1,33 & $0.00,0.03$ & 0.13 & 0.726 \\
\hline $\mathrm{S} \times \mathrm{L} \times \mathrm{D}$ & 1,33 & $0.02,0.03$ & 0.79 & 0.379 \\
\hline \multicolumn{5}{|l|}{ Deep zone } \\
\hline Substratum (S) & 1,33 & $0.17,0.02$ & 7.45 & $0.010^{*}$ \\
\hline Tank length (L) & 1,33 & $0.10,0.02$ & 4.37 & $0.044^{*}$ \\
\hline Drying variant (D) & 1,33 & $0.20,0.02$ & 9.09 & $0.005^{*}$ \\
\hline $\mathrm{S} \times \mathrm{L}$ & 1,33 & $0.06,0.02$ & 2.82 & 0.103 \\
\hline $\mathrm{S} \times \mathrm{D}$ & 1,33 & $0.02,0.02$ & 0.80 & 0.378 \\
\hline $\mathrm{L} \times \mathrm{D}$ & 1,33 & $0.00,0.02$ & 0.13 & 0.719 \\
\hline $\mathrm{S} \times \mathrm{L} \times \mathrm{D}$ & 1,33 & $0.00,0.02$ & 0.03 & 0.868 \\
\hline \multicolumn{5}{|c|}{ Horizontal movement: long tanks, gradual versus sudden water drop } \\
\hline \multicolumn{5}{|l|}{ Shallow zone } \\
\hline Substratum $(\mathrm{S})$ & 1,16 & $0.12,0.03$ & 4.15 & 0.059 \\
\hline Drying time $(\mathrm{T})$ & 1,16 & $0.39,0.03$ & 14.12 & $0.002 *$ \\
\hline $\mathrm{S} \times \mathrm{T}$ & 1,16 & $0.05,0.03$ & 1.85 & 0.193 \\
\hline \multicolumn{5}{|l|}{ Middle zone } \\
\hline Substratum (S) & 1,16 & $0.00,0.08$ & 0.10 & 0.762 \\
\hline Drying time $(\mathrm{T})$ & 1,16 & $0.02,0.08$ & 0.67 & 0.425 \\
\hline $\mathrm{S} \times \mathrm{T}$ & 1,16 & $0.15,0.08$ & 4.25 & 0.056 \\
\hline \multicolumn{5}{|l|}{ Deep zone } \\
\hline Substratum (S) & 1,16 & $0.09,0.02$ & 4.55 & $0.049 *$ \\
\hline Drying time $(\mathrm{T})$ & 1,16 & $0.25,0.02$ & 12.39 & $0.003 *$ \\
\hline $\mathrm{S} \times \mathrm{T}$ & 1,16 & $0.00,0.02$ & 0.14 & 0.711 \\
\hline \multicolumn{5}{|c|}{ Burying in the bottom } \\
\hline Substratum (S) & 1,16 & $0.01,0.02$ & 0.36 & 0.558 \\
\hline Drying variant (D) & 1,16 & $0.37,0.02$ & 23.07 & $<0.001 *$ \\
\hline$S \times D$ & 1,16 & $0.01,0.02$ & 0.36 & 0.558 \\
\hline
\end{tabular}

The asterisks indicate statistically significant effects 


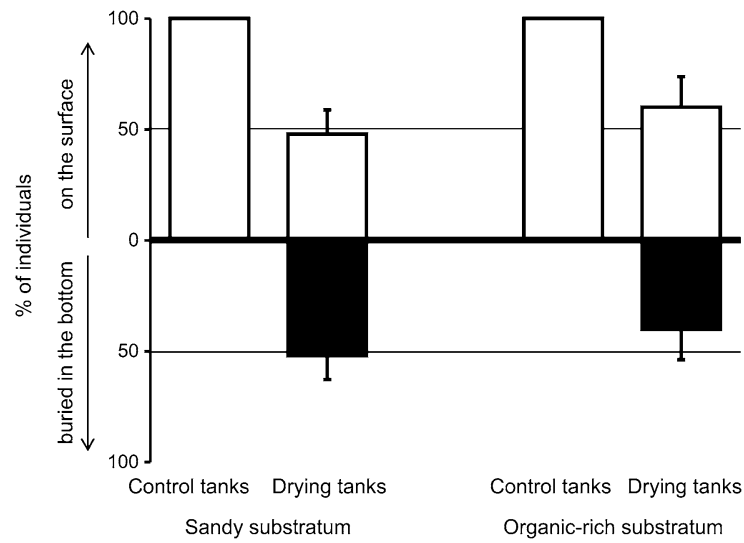

Fig. 4 Percentages of snails found on the surface (white bars) and buried in the substratum (black bars) in Experiment 3. The error bars show standard errors of means (SE)

and found that the snails have different strategies to survive that temporary air exposure.

\section{Survival}

In our experiments, $P$. corneus survived 50 days in sandy bottom and more than 53 days in organic-rich bottom. Thus, we show that this species is capable of surviving considerable periods of air exposure, which makes it adapted to live in near-shore areas or temporary water bodies. Our results confirm those by Piechocki (1979) who reported even longer, 4-5 month survival of $P$. corneus without water. Traits that make this species resistant to air exposure include large size (e.g. Byrne at al., 1988; Alonso \& Castro-Díez, 2012) and a large, thick shell (e.g. Facon et al., 2004; Collas et al., 2014), decreasing the rate of water loss. Despite their long survival, it is uncertain whether the snails in our study aestivated, as we did not observe mucus membranes typical for aestivating individuals (Parashar \& Rao, 1998).

The presence of substratum increases the survival during desiccation, as shown by much lower survival rates obtained in recent studies, in which snails were exposed without substratum (Wood et al., 2011; Collas et al., 2014). Thus, our study, in which snails could use substratum material as a shelter, seems to reflect their survival in the wild more reliably. However, it should be noted that survival may be higher in laboratory conditions compared to the field because of the lower variation in temperature and humidity (Montalto \& Ezcurra de Drago, 2003).
Snail survival may also depend on bottom type. In our study after ca 50 days of exposure all individuals exposed to air on sand died, whereas quite a large number of individuals kept on organic-rich substratum were still alive. This shows that the latter substratum is more suitable for invertebrate survival during water level decreases, most likely due to its slower drying rate and providing organisms with humid shelters among organic particles (Poznańska et al., 2010).

During prolonged air exposure snails suffer starvation, because they are inactive and thus utilise substances stored in their tissues (e.g. Goddard \& Martin, 1966; Livingstone \& de Zwaan, 1983; White et al., 2006). This also allows them to survive prolonged food deprivation, irrespective of aerial exposure. Starving planorbids Biomphalaria glabrata and Helisoma duryi survived 128 days in air (McMahon, 1983 after von Brand et al., 1957) and ca 50 days in water (von Brand et al., 1948), respectively. Thus, in our study, the snails were unlikely to die because of starvation during the duration of the experiments.

\section{Horizontal migrations}

The ability to survive prolonged desiccation and drought depends not only on physiological tolerance, as shown above, but also on behavioural strategies (Gough et al., 2012). In our experiments, P. corneus demonstrated distinct horizontal migrations following the changing water level. A prosobranch Theodoxus fluviatilis and a pulmonate Lymnaea peregra also followed the decreasing water level on vertical surfaces (Skoog, 1976), showing that this strategy is used by several snail species. In our study, these migrations were affected by the substratum type and distance to the water line, resulting in the inhibition of translocations to the submerged zone in long tanks with organic-rich bottom. Snail movement may be affected by the bottom structure (Kapps \& Haase, 2012). According to Hoffman et al. (2006) a pulmonate snail Physa sp. travelled farther on smooth substratum. Thus, uneven surface of the organic-rich substratum in our study could inhibit snail movement, making alternative survival strategies more efficient. $P$. corneus can move a distance of $15 \mathrm{~cm}$ in $2 \mathrm{~min}$ on glass or gravelly substratum (Costil \& Bailey, 1998; Jopp, 2006), keeping a constant direction over long distances (Jopp, 2006). This shows a distinct migratory potential of this species. However, we observed 
that a longer distance of ca $0.5 \mathrm{~m}$ considerably limited the ability of $P$. corneus to follow the decreasing water level on organic-rich substratum. It is likely that obstacles (small twigs or pieces of leaves) protruding from the surface could interfere with snail movement, increasing the risk of stopping or uncontrolled changes in the direction. Long crawling may also deprive a snail of energetic resources, necessary to survive an air exposure event. Thus, on the organic-rich bottom, the longer distance needed to reach a safe submerged zone, the higher the probability that a snail stops its movement and employs alternative strategies (e.g. burying) allowing it to survive a water level decrease. On the contrary, smooth sandy bottom allows for easy movement, but provides no shelter for a desiccating animal, making translocation to submerged areas a better strategy irrespective of the distance.

Our experiment showed that the rate of water level decrease also affects the selection of a defensive strategy by snails. When the water level drop was sudden, the snails remained on the exposed bottom and were unable to follow the slowly retreating water line. They could only use the substratum inclination as a cue, with downward movement being more likely to lead to a submerged zone. This strategy seems inefficient on an uneven surface, with local pits and humps. Thus, on the organic-rich substratum only few snails remained active, whereas most of them shrank their bodies into the shells and stayed in the drying bottom. On the sandy substratum, the number of migrating snails, though greater than on the organicrich bottom, was also reduced compared to their distribution in response to a slow water level drop. This shows that $P$. corneus can adjust its behaviour to local conditions and select a defensive strategy depending on the scale and rapidity of a water level decrease.

\section{Vertical migrations}

Survival in air-exposed areas can be facilitated by burying behaviour, particularly when migration following the retreating water level is not possible. In our experiments $P$. corneus burrowed just below the substratum surface, similarly to some other gastropods (Duft et al., 2003) and bivalves (Gough et al., 2012), whereas other pulmonate species from temporary ponds bury to depths as great as $7 \mathrm{~cm}$ (McMahon, 1983 after Cheatum, 1934). Survival time during drought may be increased in the field, if snails can find relatively humid, protected microhabitats in the sediments (Machin, 1975; Facon et al., 2004; Collas et al., 2014). Shallow burrowing in moist substratum to decrease temperature is a very efficient strategy to survive desiccation, particularly if a species exhibits additional physiological adaptations to live inside sediments (Gough et al., 2012). Buried snails decrease activity and switch to purely cutaneous breathing or anaerobic metabolism (Machin, 1975; McMahon, 1983), which makes them highly tolerant to anoxia. However, too deep burial in the sediments is likely to decrease their survival, as digging out from under a layer of dried substratum may be energetically costly and difficult. This might have resulted in the shallow burying of $P$. corneus in our study.

\section{Conclusions}

Our experimental data demonstrated physiological tolerance as well as behavioural adaptations of $P$. corneus to water level decrease, air exposure and substratum drying. The tested snails migrated horizontally following the decreasing water level and, when this strategy was hindered, were able to survive for a long time in dry substratum. Their survival could be further prolonged by burying into sediments, exhibited by ca $50 \%$ of air-exposed individuals. These findings broaden our knowledge of mechanisms underlying success of the pulmonate snails in environments experiencing large water level fluctuations, such as temporary ponds and river banks. Moreover, various aspects of aerial survival of different aquatic organisms are important not only in the context of water level fluctuations but also in determining their spreading potential by means of aerial migratory vectors (Facon et al., 2004; Alonso \& Castro-Díez, 2012) and should receive further research.

Acknowlegements This research was supported by Polish National Science Centre (NSC Grant No. NN304 306840). We wish to thank Marta Budka, MSc, who helped us to collect snails as well as Professor Andrzej Piechocki and Dr. Anna Drozd, who provided us with access to the appropriate literature.

Open Access This article is distributed under the terms of the Creative Commons Attribution License which permits any use, distribution, and reproduction in any medium, provided the original author(s) and the source are credited. 


\section{References}

Abbaspour, M., A. H. Javid, S. A. Mirbagheri, F. Ahmadi Givi \& P. Moghimi, 2012. Investigation of lake drying attributed to climate change. International Journal of Environmental Science and Technology 9: 257-266.

Akande, I. S., A. A. Odetola, T. A. Samuel \& P. N. Okolie, 2010. Biochemical evaluation of aestivation and starvation in two snail species. African Journal of Biotechnology 9(45): 7718-7723.

Alâkrinskaâ, I. O., 1971. Nekotore adaptacii Mytilus galloprovincialis (Bivalvia) i Planorbis corneus (Gastropoda) $\mathrm{k}$ otsustviû wody. Selected adaptations of Mytilus galloprovincialis (Bivalvia) and Planorbis corneus (Gastropoda) for absence of water. Zoologichesky Žhurnal, Moskva 50: 648-656.

Aldridge, D. W., 1983. Physiological ecology of freshwater prosobranchs. In Russell-Hunter, W. D. (ed.), The Mollusca Ecology, Vol. 6. Academic Press, INC., Orlando, FL: 329-358.

Alonso, A. \& P. Castro-Díez, 2012. Tolerance to air exposure of the New Zealand mudsnail Potamopyrgus antipodarum (Hydrobiidae, Mollusca) as a prerequisite to survival in overland translocations. NeoBiota 14: 67-74.

Brauns, M., X.-F. Garcia \& M. T. Pusch, 2008. Potential effects of water-level fluctuations on littoral invertebrates in lowland lakes. Hydrobiologia 613: 5-12.

Byrne, R. A., R. F. Mcmahon \& T. H. Dietz, 1988. Temperature and relative humidity effects on aerial exposure tolerance in the freshwater bivalve Corbicula fluminea. Biological Bulletin 175: 253-260.

Cheatum, E. P., 1934. Limnological investigations on respiration, annual migratory cycle and other related phenomena in fresh water pulmonte snails. Transactions of the American-Microscopical Society 53: 348-407.

Collas, F. P. L., K. R. Koopman, A. J. Hendriks, G. van der Velde, L. N. H. Verbrugge \& R. S. E. W. Leuven, 2014. Effects of desiccation on native and non-native molluscs in rivers. Freshwater Biology 59: 41-55.

Coops, H., M. Beklioglu \& T. L. Crisman, 2003. The role of water-level fluctuations in shallow lake ecosystemsworkshop conclusions. Hydrobiologia 506-509: 23-27.

Costil, K. \& B. Clement, 1996. Relationship between freshwater gastropods and plant communities reflecting various trophic levels. Hydrobiologia 321: 7-16.

Costil, K. \& S. E. R. Bailey, 1998. Influence of water temperature on the activity of Planorbarius corneus (L.) (Pulmonata, Planorbidae). Malacologia 39(1-2): 141-150.

Costil, K., G. B. J. Dussart \& J. Daguzan, 2001. Biodiversity of aquatic gastropods in the Mont St-Michel basin (France) in relation to salinity and drying of habitats. Biodiversity and Conservation 10: 1-18.

Duft, M., U. Schulte-Oehlmann, M. Tillmann, B. Markert \& J. Oehlmann, 2003. Toxicity of triphenyltin and tributyltin to the freshwater mudsnail Potamopyrgus antipodarum in a new sediment biotest. Environmental Toxicology and Chemistry 22(1): 145-152.

Extence, C. E., 1981. The effect of drought on benthic invertebrate communities in lowland river. Hydrobiologia 83 : 217-224.
Facon, B., E. Machline, J. P. Pointier \& P. David, 2004. Variation in desiccation tolerance in freshwater snails and its consequences for invasion ability. Biological Invasions 6: 283-293.

Ferreira, M. V. R., A. C. R. Alencastro \& M. Hermes-Lima, 2003. Role of antioxidant defenses during estivation and anoxia exposure in the freshwater snail Biomphalaria tenagophila (Orbigny, 1835). Canadian Journal of Zoology 81: 1239-1248.

Furey, P. C., R. N. Nordin \& A. Mazumder, 2004. Water level drawdown affects physical and biogeochemical properties of littoral sediments of a reservoir and natural lake. Lake and Reservoir Management 20(4): 280-295.

Ghiretti, F. \& A. Ghiretti-Magaldi, 1975. Respiration. In Fretter, V. \& J. Peake (eds), Pulmonates: Functional Anatomy and Physiology, Vol. 1. Academic Press, London: 33-51.

Goddard, C. K. \& A. W. Martin, 1966. Carbohydrate metabolism. In Wilbur, K. M. \& C. M. Yonge (eds), Physiology of Mollusca, Vol. II. Academic Press, London: 275-308.

Gough, H. M., A. M. G. Landis \& J. A. Stoeckel, 2012. Behaviour and physiology are linked in the responses of freshwater mussels to drought. Freshwater Biology 57(11): 2356-2366.

Hoffman, A. L., J. D. Olden, J. B. Monroe, N. L. Poff, T. Wellnitz \& J. A. Wiens, 2006. Current velocity and habitat patchiness shape stream herbivore movement. Oikos 115 : 358-368.

Jopp, F., 2006. Comparative studies on the dispersal of the Great Ramshorn (Planorbarius corneus L.): a modelling approach. Limnologica 36: 17-25.

Jurkiewicz-Karnkowska, E., 2008. Aquatic mollusc communities in riparian sites of different size, hydrological connectivity and succession stage. Polish Journal of Ecology 56(1): 99-118.

Kappes, H. \& P. Haase, 2012. Slow, but steady: dispersal of freshwater molluscs. Aquatic Sciences 74: 1-14.

Klekowski, R. Z., 1959. Przeżywalność wysychających ślimaków Planorbis planorbis L. w zależności od niektórych warunków środowiska. Survival of desiccating molluscs Planorbis planorbis L. in dependence on some environmental conditions. English summary. Polish Archives of Hydrobiology 5(18): 71-89.

Livingstone, D. R. \& A. de Zwaan, 1983. Carbohydrate metabolism of gastropods. In Hochachka, P. W. (ed.), The Mollusca, Vol. 1., Metabolic Biochemistry and Molecular Biomechanics Academic Press, New York: 177-242.

Lodge, D., 1985. Macrophyte-gastropod associations: observations and experiments on macrophyte choice by gastropods. Freshwater Biology 15: 695-708.

Machin, J., 1975. Water relationship. In Fretter, V. \& J. Peake (eds), Pulmonates: Functional Anatomy and Physiology, Vol. 1. Academic Press, London: 105-163.

McMahon, R. F., 1983. Physiological ecology of freshwater pulmonates. In Russell-Hunter, W. D. (ed.), The Mollusca Ecology, Vol. 6. Academic Press, INC., Orlando, FL: 359-430.

Montalto, L. \& I. Ezcurra de Drago, 2003. Tolerance to desiccation of an invasive mussel, Limnoperna fortunei (Dunker, 1857) (Bivalvia, Mytilidae), under experimental conditions. Hydrobiologia 498: 161-167. 
Nowakowska, A., 2011. Hypometabolism in land snails: controlled or passive phenomenon? In Nowakowska, A. \& M. Ł. Caputa (eds), Hypometabolism: Strategies of Survival in Vertebrates and Invertebrates. Research Signpost, Kerala: 1-17.

Overpeck, J. \& B. Udall, 2010. Dry times ahead. Science 328: 1642-1643.

Parashar, B. D. \& K. M. Rao, 1998. A novel mechanism for protection against desiccation in a freshwater planorbid snail, Indoplanorbis exustus, vector of animal schistosomiasis in India. South African Journal of Science 94(11): 567-568.

Piechocki, A., 1979. Fauna słodkowodna Polski. Mięczaki (Mollusca), ślimaki (Gastropoda). Freshwater fauna of Poland. Molluscs (Mollusca), gastropods (Gastropoda). PWN, Warszawa.

Poznańska, M., J. Kobak, N. Wolnomiejski \& T. Kakareko, 2009. Macroinvertebrate community of the near-shore zone in the limnic part of a lowland dam reservoir. Limnologica 39: 163-179.

Poznańska, M., J. Kobak, N. Wolnomiejski \& T. Kakareko, 2010. Macrozoobenthos communities from two types of land-water transition zones in a European lowland dam reservoir. Fundamental and Applied Limnology 176: 115-126.

Poznańska, M., T. Kakareko, M. Krzyżyński \& J. Kobak, 2013. Effect of substratum drying on the survival and migrations of Ponto-Caspian and native gammarids (Crustacea: Amphipoda). Hydrobiologia 700: 47-59.

Precht, T. H., 1939. Die Resistenz gegen Austrocknung bei Planorbiden. Zoologie Anzeige 128: 124-135.

Richards, C. S., 1967. Estivation of Biomphalaria glabrata (Basommatophora: Planorbidae). The American Journal of Tropical Medicine and Hygiene 16(6): 797-802.

Richardson, S. M., J. M. Hanson \& A. Locke, 2002. Effects of impoundment and water-level fluctuations on macrophyte and macroinvertebrate communities of a dammed tidal river. Aquatic Ecology 36: 493-510.
Skoog, G., 1976. Effects of acclimatization and physiological state on the tolerance to high temperatures and reactions to desiccation of Theodoxus fluviatilis and Lymnaea peregra. Oikos 27: 50-56.

Tanveer, A. \& D. Kahn, 1989. Seasonal variations in the environmental factors and snail populations in four different habitats around Lahore. Punjab University Journal of Zoology 4: 31-69.

Underwood, G. J. C., J. D. Thomas \& J. H. Baker, 1992. An experimental investigation of interactions in snail-macrophyte-epiphyte systems. Oecologia 91: 587-595.

van Vliet, M. T. H. \& J. J. G. Zwolsman, 2008. Impact of summer droughts on the water quality of the Meuse river. Journal of Hydrology 353: 1-17.

von Brand, T., M. O. Nolan \& E. Rogers Mann, 1948. Observations on the respiration of Australorbis glabratus and some other aquatic snails. Biological Bulletin 95(2): 199-213.

von Brand, T., H. D. Baernstein \& B. Mehlman, 1950. Studies on the anaerobic metabolism and the aerobic carbohydrate consumption of some freshwater snails. Biological Bulletin 98: 266-276.

von Brand, T., P. McMahon \& M. O. Nolan, 1957. Physiological observation on starvation and desiccation of the snail Australorbis glabratus. Biological Bulletin 113: 89-102.

White, M. M., B. Fried \& J. Sherma, 2006. Determination of the effects of estivation and starvation on neutral lipids and phospholipids in Biomphalaria glabrata (NMRI Strain) and Helisoma trivolvis (Colorado Strain) snails by quantitative high performance thin layer chromatography-densitometry. Journal of Liquid Chromatography and Related Technology 29: 2167-2180.

Wood, A. M., C. R. Haro, R. J. Haro \& G. J. Sandland, 2011. Effects of desiccation on two life stages of an invasive snail and its native cohabitant. Hydrobiologia 675: 167-174. 